\title{
Microbial transformation of nitroaromatic compounds under anaerobic conditions
}

\author{
ThOMAS GorontZy, JAN KÜVER and KaRL-HeinZ BloteVogel** \\ Fachbereich Biologie, AG Mikrobiologie, Universität Oldenburg, Postfach 25 03, W-2900 Oldenburg, \\ Federal Republic of Germany
}

(Received 5 October 1992; revised 14 January 1993; accepted 20 January 1993)

\begin{abstract}
The transformation of several mono- and dinitroaromatic compounds (tested at 50-200 $\mu \mathrm{M}$ ) by methanogenic bacteria, sulphate-reducing bacteria and clostridia was studied. Some of the nitroaromatics tested were transformed chemically by $1.5 \mathrm{~mm}$ quantities of culture media reducing agents, like cysteine or sulphide. This abiotic reduction occurred at the $o$-nitro-groups preferentially. Nitrophenols, $p$-nitroaniline and $p$-nitrobenzoic acid were completely transformed biologically into the corresponding amino derivatives. The nitroaromatics were transformed by all of the bacterial strains tested. While growing cells of sulphate-reducing bacteria and Clostridium spp. carried out nitroreduction, methanogen cells lysed in the presence of nitroaromatics. Nevertheless these culture suspensions converted nitroaromatics to the corresponding amino derivatives. This was also confirmed by crude cell extracts of methanogenic bacteria. The rate of nitroreduction by sulphate-reducing bacteria depended on the electron donors supplied and the cell density, with molecular hydrogen being the most effective donor of reducing equivalents. The toxicity of $p$-nitrophenol to some of the organisms tested depended on the concentration of the nitroaromatic compound and the type of organism.
\end{abstract}

\section{Introduction}

Nitroaromatic compounds are released into the environment in large quantities, since they are widely used not only as pesticides, but also as explosives and precursors for dyes, pharmaceuticals and plastics. They are also formed during incineration of organic compounds and synthesized photochemically in the atmosphere (Gibson, 1982). Some nitroaromatic compounds, such as 1-nitropyrene, are highly mutagenic and/or carcinogenic (Thiem et al., 1979), and several nitroaromatics are potent uncouplers of oxidative and photosynthetic phosphorylation (Terada, 1981; Shea et al., 1983). Once released into the environment, nitroaromatics underlie complex physical, chemical, and biological processes. Depending on the prevailing conditions they may be transformed photochemically (Nakagawa \& Crosby, 1974), or reduced electrochemically (Macalady et al., 1986). Nitroaromatics can also be transformed by micro-organisms under aerobic

\footnotetext{
*Author for correspondence. Tel. 441 7980; fax 4417983250.

Abbreviations: p-NP, p-nitrophenol; p-AP, $p$-aminophenol; m-NP, $m$-nitrophenol; $\mathrm{p}$-NB, $p$-nitrobenzoic acid.
}

conditions (Germanier \& Wuhrmann, 1963; Zeyer \& Kearney, 1984; Schackmann \& Müller, 1991; Spain \& Gibson, 1991). Little is known about the transformation of nitroaromatics by growing cultures of anaerobic bacteria. Transformation reactions have been examined mostly in mixed cultures and enzyme preparations (Boyd et al., 1983; Hallas \& Alexander, 1983; Zeyer \& Kearney, 1984; Blotevogel \& Butte, 1989). Specific nitroreductases catalysing the reduction of nitro-groups of aromatics to amino-groups have been isolated and characterized (Kinoushi \& Ohnishi, 1983; Bryant \& DeLuca, 1991; Rafii et al., 1991). One of these enzymes acts as an electron carrier protein for the artificial electron-acceptor menadione, indicating quinone reductase activity (Bryant \& DeLuca, 1991).

The present study was performed to investigate the behaviour of nitroaromatics in the presence of pure cultures of sulphate-reducing bacteria, methanogenic bacteria, and Clostridium spp., as well as the effect of nitroaromatics on these bacteria.

\section{Methods}

Strains of bacteria. The following strains of bacteria were used: Methanobacterium formicicum (DSM 1535), Methanobacterium thermo- 
autotrophicum (DSM 1053), Methanosarcina barkeri (DSM 800), Methanosarcina frisia (DSM 3318), Methanosarcina sp. KS2002 (isolated from sewage sludge), Methanospirillum hungatei (DSM 864), Methanogenium tationis (DSM 2702) and Methanoculleus oldenburgensis (DSM 6216); Desulfovibrio desulfuricans (DSM 642), Desulfovibrio gigas (DSM 496), Desulfovibrio sp. AS (isolated from sediment from the river Amazon, Brazil), Desulfovibrio sp. HB (isolated from sewage sludge), Desulfococcus multivorans (DSM 2059), Desulfotomaculum orientis (DSM 765), Desulfotomaculum sp. GROL (isolated from a ditch sediment at Bremen, FRG); Clostridium pasteurianum (DSM 525) and Clostridium sp. W1 (isolated from soil).

Chemical transformation. An appropriate amount of each nitroaromatic compound was placed into serum flasks containing $50 \mathrm{ml}$ potassium phosphate buffer $(50 \mathrm{~mm} ; \mathrm{pH} 7.0)$ to give a final concentration of $0.2 \mathrm{~mm}$. Then the reducing agents Ti(III) nitrilotriacetate, sodium dithionite, sodium sulphide, sodium sulphite, and cysteine. $\mathrm{HCl}$ were added to give a final concentration of between 1.5 and $10.0 \mathrm{~mm}$. Before analysis the reaction mixtures were incubated at $37^{\circ} \mathrm{C}$ for one week.

Media and culture conditions. The methanogenic bacteria were cultivated and maintained as previously described (Balch et al., 1979; Blotevogel et al., 1986), with molecular hydrogen and carbon dioxide as energy and carbon sources. The sulphate-reducing bacteria were cultivated and maintained as described by Widdel \& Bak (1992). Unless otherwise indicated, the sulphate-reducing bacteria were grown with sulphate (20 mM) and lactate (20 mM) except for Desulfotomaculum sp. GROL, which was grown with butanol $(20 \mathrm{~mm})$ as energy and carbon source. The clostridia were grown in the medium described by Widdel \& Bak (1992), with $10 \mathrm{~mm}$-fructose as energy and carbon source. Experiments with added nitroaromatics were also performed under these conditions, while transformation experiments with p-NP were carried out in fed-batch culture. Samples were withdrawn every $24 \mathrm{~h}$ and the losses of p-NP, the production of p-AP, and the growth parameters were measured. All experiments were carried out at $37^{\circ} \mathrm{C}$ in triplicate.

Analytical procedures. The optical density was measured spectrophotometrically at $580 \mathrm{~nm}$. The protein content was determined as described by Bradford (1976) with bovine serum albumin as standard. Methane was analysed by gas chromatography with a Varian model 6000 gas chromatograph equipped with a thermal conductivity detector. The injector and the detector were heated to $70^{\circ} \mathrm{C}$ and $180^{\circ} \mathrm{C}$, respectively; the oven temperature was $50^{\circ} \mathrm{C}$. The gases were separated from each other in a $2 \mathrm{~m}$ glass column packed with Porapac $\mathrm{Q}$ (Supelco) with $30 \mathrm{ml} \mathrm{N}_{2} \mathrm{~min}^{-1}$ as a carrier gas.

The nitroaromatic and aminoaromatic compounds were measured by means of UV/VIS-spectrophotometry based on their specific absorbance at a certain wavelength (Alexander \& Lustigman, 1966; Hallas \& Alexander, 1983). Absorption spectra were taken from 200 to $500 \mathrm{~nm}$ after precipitating the hydrogen sulphide in the $1 \mathrm{ml}$ sample with $0.1 \mathrm{ml} 2 \%(\mathrm{w} / \mathrm{v})$ zinc acetate solution. Reference spectra of the nitro- and aminoaromatics $(20-1000 \mu \mathrm{M})$ were determined in phosphate-buffered standard solutions (10 mM; $\mathrm{pH} 7 \cdot 2)$. Disappearance of nitrophenols and production of aminophenols was determined by reverse-phase HPLC [LiChrosorb $\mathrm{Cl} 8(10 \mu \mathrm{m})$; eluent $\mathrm{H}_{2} \mathrm{O}$ /methanol/

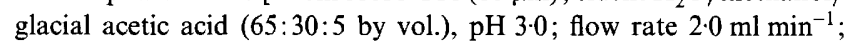
detection UV $254 \mathrm{~nm}$ ].

Chemicals. All chemicals were of reagent grade and were obtained from Serva, Fluka or Janssen. For the preparation of $100 \mathrm{~mm}$ stock solutions the nitroaromatics and aminoaromatics were dissolved in deionized distilled water with the exception of 2,4-dinitrophenol, which was dissolved in methanol $(97 \%, \mathrm{v} / \mathrm{v})$.

\section{Results}

Chemical reduction of nitroaromatics by medium constituents and possible metabolic products

In order to differentiate chemical from biological transformation reactions it was first necessary to study the behaviour of the nitroaromatics in the presence of typical reducing agents which are used for the preparation of media for anaerobic bacteria (Table 1). oNitrophenol (o-NP) was completely reduced chemically to its corresponding amino derivative by the reducing agents sulphide and/or cysteine. Therefore it was not used to study biological transformation. The transformation of 2,4-dinitrophenol (2,4-DNP) by sulphide and cysteine resulted in the formation of 2-amino-4nitrophenol; $p$-nitroaniline (p-NA) was transformed to an unidentified product under the same conditions. Ti(III) nitrilotriacetate (Ti-NTA) and sodium dithionite caused a complete transformation of every nitroaromatic compound tested into the corresponding amino- or diamino-derivative; therefore these compounds were not used in biological transformation experiments.

\section{Reduction of nitroaromatics by growing cultures of bacteria}

Uninoculated and autoclaved controls showed no transformation of the nitroaromatics tested. Only 2,4dinitrophenol and $p$-nitroaniline were partially transformed by media reducing agents. All of the organisms studied were able to perform the transformation of nitroaromatic compounds and to complete the partial transformation of 2,4-dinitrophenol and $p$-nitroaniline (Table 2). Desulfococcus multivorans and Desulfotomaculum orientis only transformed $p$-nitrophenol. Transformation always resulted in the formation of amino-

\section{Table 1. Transformation of several nitroaromatic compounds by reducing agents}

Experiments were carried out at $\mathrm{pH} 7.2$ and $37^{\circ} \mathrm{C}$ for $7 \mathrm{~d}$. Each reducing agent was tested at $1.5-10 \mathrm{mM}$.

\begin{tabular}{lccccc}
\hline \hline \multirow{2}{*}{$\begin{array}{c}\text { Nitroaromatic } \\
\text { compound } \\
(0-5 \mathrm{mM})\end{array}$} & \multicolumn{5}{c}{ Reducing agent* } \\
\cline { 2 - 6 } & Ti-NTA & Dithionite & Sulphite & Sulphide & Cysteine \\
\hline p-NP & + & + & - & - & - \\
m-NP & + & + & - & - & - \\
o-NP & + & + & - & + & + \\
$2,4-D N P$ & + & + & - & \pm & \pm \\
p-NB & + & + & - & - & - \\
p-NA & + & + & - & \pm & \pm \\
\hline \hline
\end{tabular}

*Ti-NTA, Ti(III) nitrilotriacetate; +, complete transformation into the corresponding amino derivative; \pm , partial transformation;,- , no transformation 
Table 2. Transformation of several nitroaromatic compounds by growing cultures of methanogenic bacteria, sulphate-reducing bacteria and Clostridium

The compounds were used at $50 \mu \mathrm{M}, 100 \mu \mathrm{M}$ and $100 \mu \mathrm{M}$ for the three groups of bacteria respectively. Experiments were carried out in typical media for $7 \mathrm{~d}$ (except $M s$. barkeri and Methanosarcina sp. KS2002, which were incubated for $14 \mathrm{~d}$ at $\mathrm{pH} 7 \cdot 0-7 \cdot 2$ and $30^{\circ} \mathrm{C} / 37^{\circ} \mathrm{C}$. Complete transformation of the nitroaromatics was ascertained by UV/VIS and HPLC. The abiotically transformed nitroaromatics 2,4-dinitrophenol and $p$-nitroaniline were investigated for complete transformation by the listed organisms.

\begin{tabular}{|c|c|c|c|c|c|}
\hline \multirow[b]{2}{*}{ Organism } & \multicolumn{5}{|c|}{ Nitroaromatic compound* } \\
\hline & $\mathrm{p}-\mathrm{NP}$ & $\mathrm{m}-\mathrm{NP}$ & 2,4-DNP & $\mathrm{p}-\mathrm{NB}$ & $\mathrm{p}-\mathrm{NA}$ \\
\hline \multicolumn{6}{|l|}{ Methanobacterium } \\
\hline formicicum & + & + & + & + & + \\
\hline thermoautotrophicum & + & + & + & + & + \\
\hline \multicolumn{6}{|l|}{ Methanospirillum } \\
\hline hungatei & + & + & + & + & + \\
\hline \multicolumn{6}{|l|}{ Methanosarcina } \\
\hline barkeri & + & + & + & + & + \\
\hline frisia & + & + & + & + & + \\
\hline sp. KS2002 & + & + & + & + & + \\
\hline \multicolumn{6}{|l|}{ Methanogenium } \\
\hline tationis & + & + & + & + & + \\
\hline \multicolumn{6}{|l|}{ Methanoculleus } \\
\hline oldenburgensis & + & + & + & + & + \\
\hline \multicolumn{6}{|l|}{ Desulfovibrio } \\
\hline desulfuricans & + & + & + & + & + \\
\hline gigas & + & + & + & + & + \\
\hline sp. AS & + & + & + & + & + \\
\hline sp. HB & + & + & + & + & + \\
\hline \multicolumn{6}{|l|}{ Desulfococcus } \\
\hline multivorans & + & - & - & - & - \\
\hline \multicolumn{6}{|l|}{ Desulfotomaculum } \\
\hline orientis & + & - & - & - & - \\
\hline sp. GROL & + & + & + & + & + \\
\hline \multicolumn{6}{|l|}{ Clostridium } \\
\hline pasteurianum & + & + & + & + & + \\
\hline sp. W1 & + & + & + & + & + \\
\hline
\end{tabular}

$*+, 100 \%$ transformation into the corresponding amino derivative; - , no transformation.

aromatics as ascertained by UV/VIS-spectrophotometry and HPLC.

As a typical representative of the sulphate-reducing bacteria, Desulfovibrio gigas was studied more extensively. The nitro-group reduction $(0.1 \mathrm{~mm}$ each maximally) by growing cultures of Desulfovibrio gigas was strongly correlated with the growth phase (Fig. 1). Controls without added nitroaromatics showed the same course of growth. The maximum rate of p-NP transformation during the exponential phase of growth was around $0.28 \mu \mathrm{mol}$ (mg protein) $)^{-1} \mathrm{~h}^{-1}$.

The two Clostridium species studied were also able to completely transform all the nitroaromatics tested to their corresponding amino derivatives (Table 2). The Clostridium spp. showed the same transformation behaviour as Desulfovibrio gigas. Again the course of growth was not affected by the nitroaromatic compound. The maximum rate of $\mathrm{p}$-NP transformation during the exponential phase of growth was about $0.42 \mu \mathrm{mol}(\mathrm{mg}$ protein $)^{-1} h^{-1}$.
The transformation of nitroaromatic compounds by methanogenic bacteria only occurred while cells lysed. Therefore it was necessary to pregrow the cells to an optical density of about $0 \cdot 15$ before adding the nitroaromatics. As shown in Table 2, all of the methanogens tested were able to perform a complete transformation of the nitroaromatics. Methanosarcina frisia was investigated in more detail. The results in Fig. 2 indicate that p-NP was transformed by growing cultures of Methanosarcina frisia $\left(\mathrm{OD}_{580} 0.15\right)$ accompanied by a decrease in the optical density. As long as p-NP was present, the methane production ceased entirely. When transformation had been completed, growth and methane production of Methanosarcina frisia recovered.

\section{Effect of different electron donors on the rate of nitroaromatic reduction by Desulfovibrio gigas}

Further experiments with Desulfovibrio gigas showed that different electron donors affected the p-NP trans- 


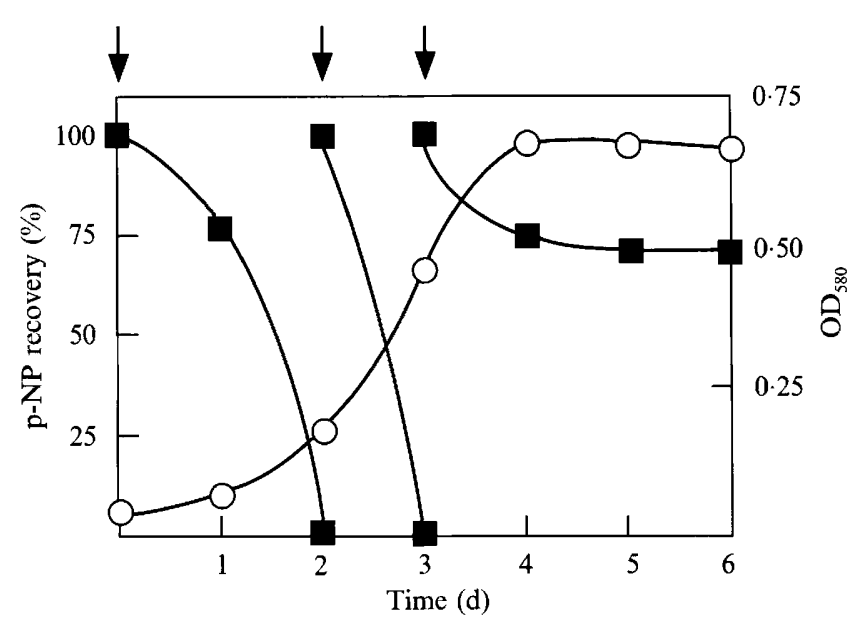

Fig. 1. Repeated transformation of p-NP $(100 \mu \mathrm{M})$ by cultures of Desulfovibrio gigas with lactate and sulphate (each $20 \mathrm{mM}$ ) as carbon and energy sources. $\mathrm{O}, \mathrm{OD}_{580} ; \mathbf{n}, \mathrm{p}-\mathrm{NP}$ recovery $(\%)$; addition of p-NP $(100 \mu \mathrm{M})$.

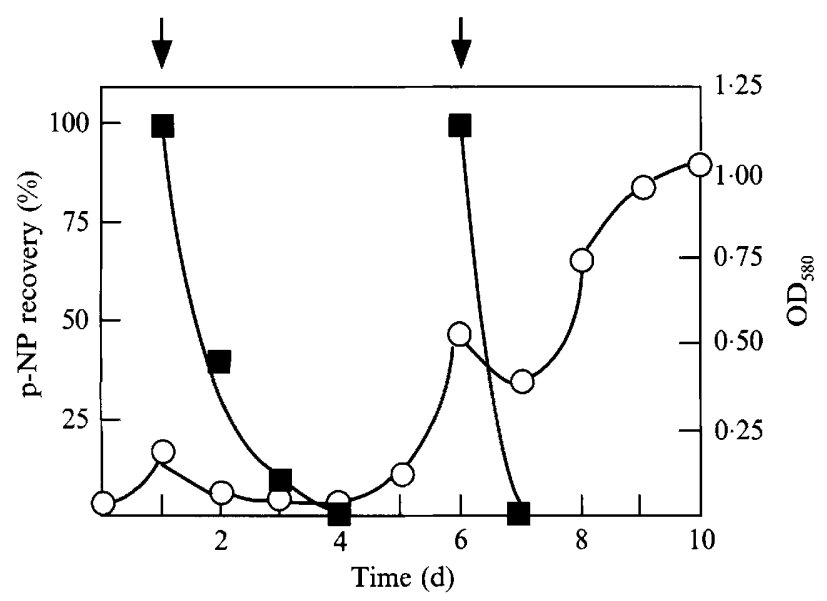

Fig. 2. Repeated transformation of p-NP $(50 \mu \mathrm{M})$ by cultures of Methanosarcina frisia with molecular hydrogen and carbon dioxide as carbon and energy sources. $\mathrm{O}, \mathrm{OD}_{580} ; \boldsymbol{\square}, \mathrm{p}-\mathrm{NP}$ recovery $(\%)$; † addition of p-NP $(50 \mu \mathrm{M})$.

formation differently (Fig. $3 a$ ). The following sequence of transformation velocity could be observed: molecular hydrogen $>$ pyruvate $>$ lactate $>$ ethanol. Except in the case of molecular hydrogen the transformation velocity was correlated with the specific growth rates and the biomass yields (Fig. $3 b$ ). With molecular hydrogen the transformation was completed within the early stages of the exponential-phase of growth.

\section{Effect of nitro- and aminoaromatics on growth}

Concentrations of p-NP higher than $0.2 \mathrm{~mm}$ impaired the growth of Desulfovibrio gigas, which became apparent by an extended lag phase. A concentration of $1.0 \mathrm{~mm}$ led to complete inhibition of growth. The transformation
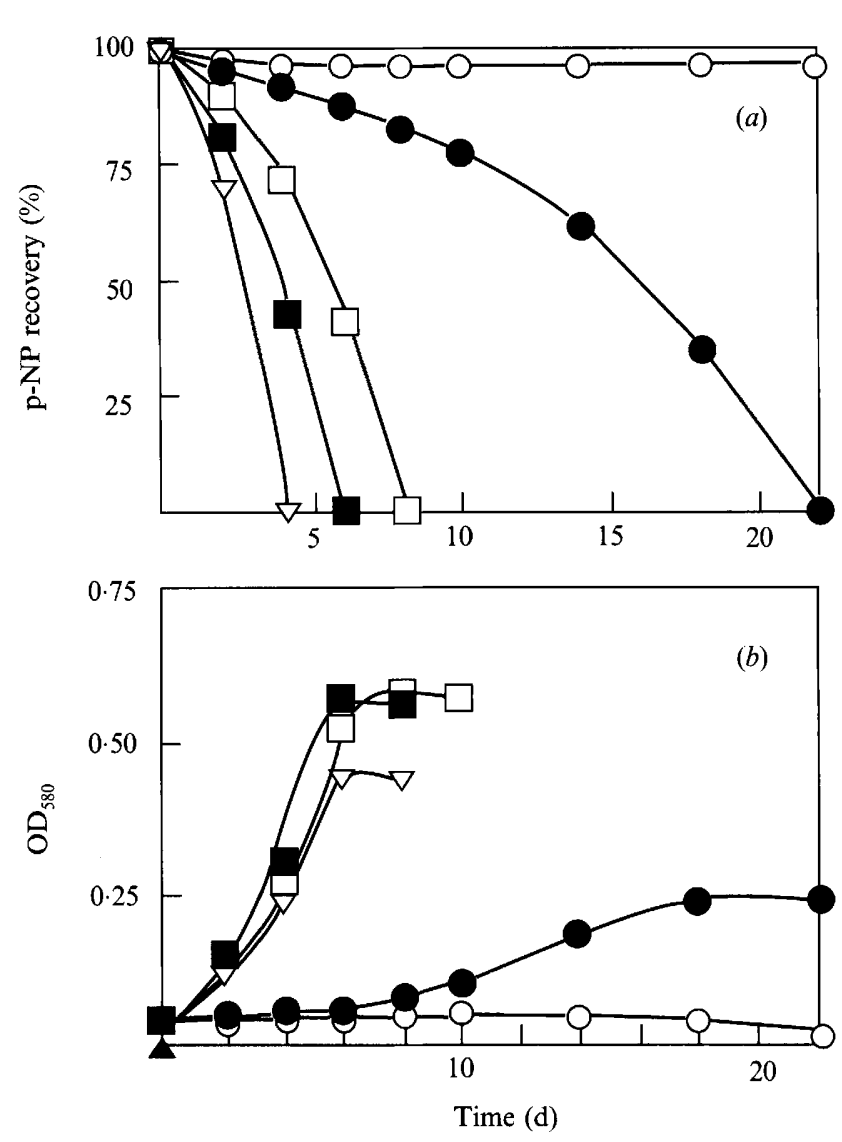

Fig. 3. (a) Influence of different carbon and energy sources on the reduction of p-NP $(200 \mu \mathrm{M})$ by growing cultures of Desulfovibrio gigas. (b) Growth of $D v$. gigas with different energy and carbon sources in the presence of $200 \mu \mathrm{M}$ p-NP. $\bigcirc$, Control; 9 , ethanol (30 mM); $\square$, lactate $(20 \mathrm{~mm}) ; \boldsymbol{\square}$, pyruvate $(20 \mathrm{mM}) ;$ and $\nabla, \mathrm{H}_{2} / \mathrm{CO}_{2}$ plus acetate $(20 \mathrm{~mm})$.

product $p$-aminophenol (p-AP; 0.1 to $10 \mathrm{mM}$ ) did not influence growth. Similar results were obtained with Clostridium pasteurianum, but this organism tolerated higher concentrations of p-NP than did Desulfovibrio gigas. Complete inhibition of growth of Clostridium pasteurianum was observed in the presence of $5.0 \mathrm{mM}-$ p-NP. The transformation product p-AP did not influence the growth of this organism nor the growth of Methanosarcina frisia.

\section{Discussion}

Our results conclusively show that under anaerobic conditions nitroaromatics were converted into the corresponding amino compounds by living bacteria as well as abiotically. Chemical transformation occurred in the presence of media-reducing compounds like sulphide or Ti(III) nitrilotriacetate (Table 1). In the case of $o$-nitrophenol and 2,4-dinitrophenol, nitro-group transformation occurred only in the ortho-position; the transformation product of $p$-nitroaniline is not known. 
In contrast to recent findings (Macalady et al., 1986), our results clearly demonstrate that nitroaromatics $(0 \cdot 2 \mathrm{mM})$ can be reduced directly by certain reductants $(1.5 \mathrm{mM})$. A chemical transformation of 2,4,6-trinitrotoluene to 2,4-diamino-6-nitrotoluene by sulphide ions was also observed (Preuss et al., 1990).

Biological transformation of certain nitroaromatics by cell-free extracts of anaerobic bacteria has been observed in Clostridium spp. (O'Brien \& Morris, 1971; Angermaier \& Simon, 1983; Rafii et al., 1991), Bacteroides fragilis (Kinoushi \& Ohnishi, 1983), Veillonella alcalescens (McCormick et al., 1976) and Enterobacter cloacae (Bryant \& DeLuca, 1991). Our results extend this range of species for which transformation has been demonstrated to some strains of sulphate-reducing and methanogenic bacteria (Table 2). According to other authors (Boyd et al., 1983; Battersby \& Wilson, 1989) the reductive transformation of nitroaromatic compounds leads to a detoxification of the substance.

Methanogenic bacteria lysed in the presence of nitroaromatics. This was correlated with the reduction of the nitro-substituent to the corresponding amino-group. In Fig. 2 the behaviour of Methanosarcina frisia in the presence of $50 \mu \mathrm{M}$ p-NP is shown. Cell lysis does not depend on the type of nitroaromatic compound. This may be the reason why methanogenesis is inhibited by nitroaromatics during anaerobic sewage treatment (Horowitz et al., 1982; Boyd et al., 1983; Johnson \& Young, 1983). However, Fedorak et al. (1990) found no evidence that anilines negatively influenced methanogenesis. This was also confirmed in our experiments: after the reduction of the nitro-substituent, the resulting aminoaromatic molecule no longer hindered cell growth. Additionally, other aminoaromatics did not cause cell lysis. Therefore we assumed that nitroaromatics or intermediates of the reduction process like nitroso- or hydroxylamines are the real toxicants, since they may react with the unique cell membrane components of the methanogens.

A second toxic function of a nitroaromatic compound might be determined by the fact that it acts as an 'electron trap'. This has already been assumed for the oxygen sensitivity of methanogens (Jarrell, 1985), consequently leading to the breakdown of ATP synthesis. A third possibility might be the uncoupling activity of nitroaromatics on electron transport chains thus inhibiting ATP synthesis, followed by cell lysis. Although information about the biochemistry of nitro-group reduction under methanogenic conditions is rather poor, it cannot be excluded that the coenzyme $F_{420}$ is involved in such a reaction due to its low redox potential $\left(E_{0}^{\prime}=-340 \mathrm{mV}\right)$. Apparently the methanogens were more sensitive to the presence of nitroaromatics than were the sulphate-reducing bacteria and clostridia. This is probably due to the destruction of the twofold function of the cell membranes of most methanogens as a physiological barrier and as the cell skeleton. In sulphatereducing bacteria and clostridia such a destructive effect of nitroaromatics might be prevented by the presence of a murein-containing cell wall and a different composition of the cell membrane.

In contrast to the methanogens, Clostridium spp. and sulphate-reducing bacteria reduced the nitro-substituents without cell lysis (Table 2). It is not known why Desulfococcus multivorans and Desulfotomaculum orientis only transformed $p$-nitrophenol. As shown in Fig. 1, there is a strong correlation between the growth phase and the reduction process. In addition, p-NP reduction by Desulfovibrio gigas is also dependent on the kind of electron donor. Due to the electron donor applied and the biomass yielded the following sequence of the rate of transformation of $\mathrm{p}$-NP could be measured: ethanol < lactate $<$ pyruvate $<$ hydrogen (Fig. $3 a, b$ ). To our knowledge there are no specific nitroreductases in sulphate-reducing bacteria. Hydrogenase, together with a ferredoxin-like protein, was demonstrated to function as a nitroreductase in Veillonella alcalescens and Clostridium pasteurianum (McCormick et al., 1976). A mechanism for the reduction of aromatic nitro-compounds catalysed by hydrogenase and ferredoxin was also proposed for Clostridium (Angermaier \& Simon, 1983). But other enzymes like pyruvate:ferredoxin oxidoreductases, sulphite reductases, nitrite reductases, or quinone reductases are able to transform nitroaromatics as well (Kinoushi \& Ohnishi, 1983; Bryant \& DeLuca, 1991).

No degradation of the amino-substituted aromatics was observed with the above-mentioned micro-organisms. Therefore we conclude that the reduction of nitrosubstituents in these organisms is an unspecific detoxification reaction mediated by certain enzymes and/or cofactors.

We thank Professor G. Fuchs (Ulm, FRG) for critically reading the manuscript.

\section{References}

Alexander, M. \& Lustigman, K. (1966). Effect of chemical structure on microbial degradation of substituted benzenes. Journal of Agricultural and Food Chemistry 14, 410-413.

ANGERMAIER, L. \& SimON, H. (1983). On the reduction of aliphatic and aromatic nitro compounds by Clostridia, the role of ferredoxin and its stabilization. Hoppe-Seyler's Zeitschrift für Physiologische Chemie 364, 961-975.

Balch, W. E., Fox, G. E., Magrum, L. J., Woese, C. R. \& Wolfe, R. S. (1979). Methanogens: reevaluation of a unique biological group. Microbiological Reviews 43, 260-296.

Battersby, N. S. \& Wilson, V. (1989). Survey of the anaerobic biodegradation potential of organic chemicals in digesting sludge. Applied and Environmental Microbiology 55, 433-439. 
Blotevogel, K.-H. \& Butte, W. (1989). Behaviour of nitroaromatic compounds under methanogenic conditions. In: DECHEMA Biotechnology Conferences, vol. 3B, pp. 883-887. Weinheim: VCHVerlagsgesellschaft.

BloteVogel, K.-H., Fischer, U. \& LÜPKES, K.-H. (1986). Methanococcus frisius $\mathrm{sp}$. nov., a new methylotrophic marine methanogen. Canadian Journal of Microbiology 32, 127-131.

Boyd, S. A., Shelton, D. R., BerRy, D. \& Tiedje, J. M. (1983). Anaerobic biodegradation of phenolic compounds in digested sludge. Applied and Environmental Microbiology 46, 50-54.

BRADFORD, M. M. (1976). A rapid and sensitive method for the quantitation of microgram quantities of protein utilizing the principle of protein-dye binding. Analytical Biochemistry 72, 248-254.

Bryant, C. \& DeLuCA, M. (1991). Purification and characterization of an oxygen-insensitive $\mathrm{NAD}(\mathrm{P}) \mathrm{H}$ nitroreductase from Enterobacter cloacae. Journal of Biological Chemistry 266, 4119-4125.

FedoraK, P. M., KindziersKi, W. B. \& HRudey, S. E. (1990). Effects of anilines and hydantoins on the methanogenic degradation of selected phenols. Water Research 24, 921-925.

GeRmanier, R. \& WuhrmanN, K. (1963). Über den aeroben mikrobiellen Abbau aromatischer Nitroverbindungen. Pathologia et Microbiologia 26, 569-578.

Gibson, T. L. (1982). Nitro derivatives of polynuclear aromatic hydrocarbons in airborne and source particular matter. Atmospheric Environment 16, 2037-2040.

Hallas, L. E. \& Alexander, M. (1983). Microbial transformation of nitroaromatic compounds in sewage effluent. Applied and Environmental Microbiology 45, 1234-1241.

Horowitz, A., Shelton, D. R., Cornell, C. P. \& Tiedje, J. M. (1982). Anaerobic degradation of aromatic compounds in sediments and digested sludge. Developments in Industrial Microbiology 23, 435-444.

JARRELL, K. F. (1985). Extreme oxygen sensitivity in methanogenic archaebacteria. BioScience 35, 298-302.

JoHNSON, L. D. \& YounG, J. C. (1983). Inhibition of anaerobic digestion by organic priority pollutants. Journal of the Water Pollution Control Federation 55, 1441-1450.

Kinoushi, T. \& OHNISHI, Y. (1983). Purification and characterization of 1-nitropyrene nitroreductases from Bacteroides fragilis. Applied and Environmental Microbiology 46, 596-604.
Macalady, D. L., Tratnyek, P. G. \& Grundl, T. J. (1986). Abiotic reduction reactions of anthropogenic organic chemicals in anaerobic systems: a critical review. Journal of Contaminant Hydrology 1, 1-28.

McCormick, N. G., Feeherry, F. E. \& Levinson, H. S. (1976). Microbial transformation of 2,4,6-trinitrotoluene and other nitroaromatic compounds. Applied and Environmental Microbiology 31, 949-958.

Nakagawa, M. \& Crosby, D. G. (1974). Photodecomposition of Nitrofen. Journal of Agricultural and Food Chemistry 22, 849-853.

O'BrIEN, R. W. \& Morris, J. G. (1971). The ferredoxin-dependent reduction of chloramphenicol by Clostridium acetobutylicum. Journal of General Microbiology 67, 265-271.

Preuss, A., Ecker, S., Lenke, H., Knackmuss, H. J. \& Diekert, G. (1990). Mikrobieller Abbau von TNT. DECHEMA-Symposium, Frankfurt, 1990, poster no. 37.

RafiI, F., Franklin, W., Heflich, R. H. \& Cerniglia, C. E. (1991). Reduction of nitroaromatic compounds by anaerobic bacteria isolated from the human gastrointestinal tract. Applied and Environmental Microbiology 57, 962-968.

SCHACKMANN, H. \& MÜLleR, R. (1991). Reduction of nitroaromatic compounds by different Pseudomonas species under aerobic conditions. Applied Microbiology and Biotechnology 34, 809-813.

SheA, P. J., Weber, J. B. \& Overcash, M. R. (1983). Biological activities of 2,4-dinitrophenol in plant-soil systems. Residue Reviews 87, 2-41.

Spain, J. C. \& Gibson, D. T. (1991). Pathway for biodegradation of p-nitrophenol in a Moraxella sp. Applied and Environmental Microbiology 57, 812-819.

Terada, H. (1981). The interaction of highly active uncouplers with mitochondria. Biochimica et Biophysica Acta 639, 225-242.

Thiem, K. W., Sewekow, B., Kiel, W., Handschuh, V., Freese, H., SCHIMPF, R., VAGT, H. \& Bunge, W. (1979). Nitroverbindungen, aromatische. In Ullmann's Enzyklopädie der technischen Chemie (4. Aufl.), Bd. 17, pp. 383-416. Weinheim: Verlag Chemie.

WIDDEL, F. \& BAK, F. (1992). Gram-negative mesophilic sulfatereducing bacteria. In: The Prokaryotes, vol. IV, pp. 3352-3378. Edited by A. Balows and others. New York: Springer Verlag.

ZEYER, J. \& KEARNEY, P. C. (1984). Degradation of o-nitrophenol and $\mathrm{m}$-nitrophenol by a Pseudomonas putida. Journal of Agricultural and Food Chemistry 32, 238-242. 